\title{
Pomological and quality traits of mulberry (Morus spp.) germplasm from Gorno Badakhshan in the Western Pamir
}

\author{
F. Sottile ${ }^{1}$, S. Mubalieva2 ${ }^{2}$ N.R. Giuggioli ${ }^{3, a}$ and C. Peano ${ }^{3}$ \\ ${ }^{1}$ Department of Agricultural and Forest Sciences, University of Palermo, Viale delle Scienze 11, 90128 Palermo, Italy \\ 2 Pamir Biological Institute, Khorog, Badakhshan Oblast, Tajikistan \\ ${ }^{3}$ Department of Agricultural, Forest and Food Sciences, University of Torino, Largo Paolo Braccini 2, 10095 Grugliasco \\ Torino, Italy
}

\section{Summary}

Introduction - The local fruit biodiversity can represent a good opportunity to maintain the agriculture and to develop economies in "marginal" territory such as those in the mountain rural areas. The genetic diversity of the Morus spp. is little known in the Western Pamir mountains, so that the objective of the present study was to improve the knowledge of the polymorphism of the species in the different poorly explored Tajik valleys by investigating the main quantitative and qualitative traits. Materials and methods - Six selected sites of the Gorno Badakhshan Autonomous Oblast (GBAO) region were investigated through field measurement on morphological traits of mulberry trees (both from wild and cultivated habitats). The qualitative analysis on fresh and dried fruits were carried out on four cultivars of the white mulberry (Morus alba L.) and one cultivar of the black mulberry (Morus nigra L.) collected in the Pamir Biological Institute, the highest botanical garden of the Commonwealth of Independent States (CIS). Results and discussion - our study revealed high variability for all the measured parameters confirmed by a wide polymorphism. The highest rate of variability and the most promising genotypes in terms of fruit morphological traits were observed in the Vanch and the Rushan valleys. Due to the highest ascorbic acid content for the black cv. Shatut and the white cv. Marvori and a better taste, confirmed by the highest reducing and total sugar contents during the early and the full ripening (cv. Bedonia), mulberry fruits can be suggested for the fresh consumption. The cv. Shatut is the only one suggested for sun-drying, following specific local recipes for traditional consumption. Conclusion - The high morphogenetic variability of the mulberry trees in a marginal mountain area as the Gorno Badakhshan in the Western Pamir offers opportunities to make value of fruits with high nutritional and sensory profile and to develop the agricultural resources of any vulnerable territory.

\section{Keywords}

marginal mountains area, Tajikistan, Moraceae, polymorphism, underutilized species, genetic resource management, fruit quality

a Corresponding author: nicole.giuggioli@unito.it.

\section{Significance of this study}

What is already known on this subject?

- Mulberry germplasm diversity is much appreciated in many parts of the world and its morphological characterization is well defined. It is mainly related to the various cultivation areas and it usually represents a source of income in the marginal zones.

What are the new findings?

- Our study provides an original description of the wide mulberry diversity still available in the Pamir area (Tajikistan), using both tree and fruit descriptors. The results evidence the presence of accessions well adapted for fresh consumption as well as for drying and processing, showing interesting traits in terms of qualitative and nutritional facts (high ascorbic acid content).

What is the expected impact on horticulture?

- The results show a possible role of mulberry fruit in the diet of the local population, provided the Pamir's horticulture would invest in new orchards dedicated to local markets targeting nutrition security.

\section{Résumé}

Traits pomologiques et qualitatifs des ressources génétiques en mûrier (Morus spp.) issues de Gorno Badakhshan dans le Pamir occidental.

Introduction - La biodiversité de fruits locaux représente une bonne opportunité de maintien de l'agriculture et de développement des économies dans un territoire «marginal» tel que les zones rurales de montagne. La diversité génétique des espèces du genre Morus est peu connue dans les montagnes occidentales du Pamir. L'objectif de cette étude était d'améliorer la connaissance du polymorphisme de l'espèce en étudiant les principaux traits quantitatifs et qualitatifs des plantes dans les vallées tadjikes encore peu explorées. Matériel et méthodes - Six sites sélectionnés dans la région autonome de Gorno Badakhshan Oblast (GBAO) ont été explorés. Les traits morphologiques des mûriers ont été relevés au champ (à la fois en habitats sauvage et cultivé). L'analyse qualitative sur les fruits frais et séchés a été effectuée sur quatre cultivars de mûrier blanc 
(Morus alba L.) et un cultivar de mûrier noir (Morus nigra $\mathrm{L}$.) collectés à l'Institut biologique du Pamir, le plus haut jardin botanique de la Communauté des États Indépendants (CEI). Résultats et discussion - Notre étude a révélé une grande variabilité de tous les paramètres mesurés, confirmée par un large polymorphisme. Le taux de variabilité le plus élevé et les génotypes les plus prometteurs en termes de traits morphologiques des fruits ont été observés dans les vallées de Vanch et de Rushan. En raison de la teneur en acide ascorbique la plus élevée pour le cv. Shatut (mûrier noir) et le cv. Marvori (mûrier blanc), et d'un meilleur goût du cv. Bedonia, dû à une plus forte teneur en sucres totaux et réducteurs du début à la pleine maturité, les fruits du mûrier peuvent être recommandés pour la consommation en frais. Le cv. Shatut est recommandé pour le séchage au soleil, suivant des recettes locales spécifiques pour une consommation traditionnelle. Conclusion - La grande variabilité morphogénétique des mûriers dans une zone de montagne marginale comme le Gorno Badakhshan dans le Pamir occidental, offre l'opportunité de valoriser des fruits de profil nutritionnel et gustatif élevé et de développer les ressources agricoles d'un territoire vulnérable.

\section{Mots-clés}

région montagneuse marginale, Tajikistan, mûrier Moraceae, polymorphisme, espèces sous-utilisées, gestion des ressources génétiques, qualité des fruits

\section{Introduction}

The increase of production of fruit crops and the valorization of underutilized accessions is one of the important challenges facing the agricultural sector in the Pamir mountain region of Eastern Tajikistan whose natural resources have suffered extensive damage during the ten years of civil conflict in the 1990s (Hannam, 2013).

In these mountainous areas, where is strongly expressed the lack of arable land, the cultivation and use of the crop of fruit trees is particularly important. Distinctive features such as the difficulty of the mountain terrains, the sharp temperature drops, the relative dryness of the air, the high light intensity rich in ultraviolet rays, the presence of huge glaciers, lakes and rivers, in combination with a total elevation above sea level, have distinguished this area from the other Pamir mountain regions of Central Asia (Aknazarov et al., 2002). Food security, sufficiency of power supplies, communication difficulties, and natural resource management are still critical issues (GOT, 2002). Thanks to the heterogeneous environments and to a long history of sedentary agriculture, the Tajikistan territory represents a good pool of agrobiodiversity (FAO, 2010). The indigenous cultivars of fruits trees are more suitable to local conditions and show advantages in respect to the allochthone ones (Giuliani et al., 2011), confirming old ecotypes as genetic resources of significant nutritional traits (Frison et al., 2006). Among the different fruit crop cultivars in the Pamir region, 300 apricot, 60 mulberry, 33 apple, 60 pomegranate, 26 walnut and 24 pear cultivars were identified and more than $50 \%$ of each were recognized as local (FAO, 2010). A recent study showed all the local cultivars of fruits are preferred for the household consumption while the introduced cultivars are suitable and are preferred for the processing representing a good opportunity for the improvement of the local marketing channels (Giuliani et al., 2011). Also, the history of horticulture in the Gorno Badakhshan Autonomous Oblast (GBAO) in the Eastern part of Tajikistan can be divided into different phases: the last one is well represented by a deeper study of the fruit species genetic resources and of the methods for a wider economic development of the mountain territory to improve the food availability and the technological approach to process raw materials (Middleton, 2016). Because of the high morphological variability and adaptability of the species to different (Winn, 1996) and various disruptive (Gray, 1990) environmental conditions, the mulberry is one of the most ancient of cultivated plants. The high tolerance to saline soils allows this species to play an important ecological role and its range in the world is currently reported between $50^{\circ} \mathrm{N}$ and $30^{\circ} \mathrm{S}$ latitude (El Obeidi, 2005). Although the preservation of the gene pool of the mulberry has been made mainly for sericulture (Atmakuri et al., 2009), as the plants are mainly used for the leaves, the valorization of the Morus spp. is essential for the development of the human activities and the subsistence in the poorest areas. More recently, red and black mulberry fruits are highly consumed in different countries because of their high nutritional compounds and they have gained an important position in the food industry due to the presence of anthocyanins (Ozgen et al., 2009), and other biologically active substances such as antioxidants, antimutagens and anticarcinogens (Atmakuri et al., 2009). In Tajikistan mulberry fruits are processed to obtain special traditional products such as "tut", "pikht", "bekmez" and "dosti" (respectively sun dried mulberries, ground dried mulberries, mulberry syrup and mulberry spirit), offering a good help in food consumption; however the biochemical and nutritional composition of neglected, used and commercialized cultivars is poorly known (Giuliani et al., 2011). According to previous studies to the need to balance both strategies to make conservation and commercialization of fruit cultivars (Giuliani et al., 2011), the objective of the present study was to assess the status of the mulberry biodiversity spectrum distributed in the unexplored Western Tajik Pamirs valley investigating the main morphological and biochemical characteristics of Morus spp. In addition with the aim of a better characterization of this genetic pool, potentially helpful in breeding and production, some important qualitative traits of the fruits were considered in few local cultivars grown in the Pamir Botanical Garden (2,320 m a.s.l.) in Khorog.

\section{Materials and methods}

\section{Plant material and field collections}

Field measurement on morphological traits of mulberry trees were made from both wild areas and cultivated habitats (orchards, home gardens) in the West Pamir Valley of Tajikistan; six sites of the Gorno Badakhshan Autonomous Oblast (GBAO) region were selected.

No artificial collection of mulberry trees is performed in the Pamir region, so, all the studied germplasm must be considered uniform in terms of management; even if there are different typologies of sites mentioned in the manuscript (private garden, botanical institute...) the characteristics of the source of germplasm are unique and comparable in terms of performed description.

The mulberry fits in several climatic conditions with ideal temperatures around $30^{\circ} \mathrm{C}$ and an average rainfall ranging from 1,000 up to $1,500 \mathrm{~mm}$; it is present, in the world, up 
TABLE 1. Geographical characteristics of the six selected sites in Gorno Badakhshan Autonomous Oblast (GBAO) Province for the plant collection.

\begin{tabular}{lcccc}
\hline District & Altitude $(\mathrm{m})$ & Area $\left(\mathrm{km}^{2}\right)$ & Latitude $(\mathrm{N})$ & Longitude $(\mathrm{E})$ \\
\hline Vanch & $1,600-2,500$ & 4,400 & $38^{\circ} 22^{\prime} 23^{\prime \prime}$ & $71^{\circ} 7^{\prime} 19^{\prime \prime}$ \\
Rushan & $1,900-2,500$ & 5,900 & $37^{\circ} 54^{\prime} 0^{\prime \prime}$ & $72^{\circ} 10^{\prime} 0^{\prime \prime}$ \\
Shugnan & $2,000-2,400$ & 4,600 & $37^{\circ} 37^{\prime} 0^{\prime \prime}$ & $71^{\circ} 27^{\prime} 0^{\prime \prime}$ \\
Ishkashim & $2,200-2,900$ & 3,700 & $36^{\circ} 43^{\prime} 38^{\prime \prime}$ & $71^{\circ} 36^{\prime} 42^{\prime \prime}$ \\
Roshtkala & $2,300-2,400$ & 4,300 & $37^{\circ} 16^{\prime} 0^{\prime \prime}$ & $71^{\circ} 49^{\prime} 0^{\prime \prime}$ \\
Khorog & 2,100 & 13,700 & $37^{\circ} 29^{\prime} 30^{\prime \prime}$ & $71^{\circ} 33^{\prime} 21^{\prime \prime}$ \\
\hline
\end{tabular}

to $1,000 \mathrm{~m}$ a.s.l. For this species lighting is very important for a good leaf development and for a high photosynthetic efficiency. The Pamir is a geographic area that sometimes can be also relatively dry but that is well suited to the mulberry tree in the valleys between the high mountain areas and that allows, however, to collect a lot of rain water. The climate is very variable in terms of temperatures with relatively warm summers (average temperature $27^{\circ} \mathrm{C}$ ) and winters that can be very rigid (up to $-20--25^{\circ} \mathrm{C}$ ). Winter temperatures are usually favorable in the process of preservation of agricultural products such as dried mulberries.

The altitude, latitude, longitude and dimension of each area are reported in Table 1. For each collecting site all field measurements on trees, leaves and fruits were recorded at full growth stage (code 85) of each plant after pruning according with the BBCH- identification keys (Meier, 2003). From three to fifteen plants were sampled per site depending on site and the conspicuous polymorphism. The trunk diameter was measured $400 \mathrm{~mm}$ above the ground level. The age of mulberry trees was assessed by counting the annual rings and measuring the circumference of the branches (Moustafa et al., 2014). The counting procedure, performed in the same year of the observation, was applied to the already cut branches in each site. To describe the age structure of the trees at different sites, they were scaled as follows: $<15$ years, 16-50 years, 51-100 years, > 101 years. The crown shape was estimated by the crown projection on the land with a meter (Rautiainen et al., 2008).

Measurements on leaf morphology and quantitative traits were carried out on a sample size of 50 adult leaves on three randomly selected plants per each site across the replicates. Leaf characterization has been performed following UPOV guidelines (the International Union or the Protection of New Varieties of Plants) according with the relative code (MORUS_ALB and MORUS RUB). Healthy and undamaged leaves were collected from all tree orientations, from intermediate parts of shoots. The leaf traits were measured in three consecutive years on a total of 50 randomly selected leaves from the same tree; the data are reported as an average of three years.

The fruits were characterized based on various economically important traits such as fruit weight, fruit length, fruit width, fruit shape, fruit skin colour. All sampling were performed for three consecutive years (from 15 $5^{\text {th }}$ August to $15^{\text {th }}$ September). A total of 50 randomly selected fruits from the same tree were acquired; the data are reported as an average of three years.

\section{Qualitative analysis of mulberry}

The qualitative analysis on fruits were performed on four cultivars of the white mulberry and one cultivar of the black mulberry collected in the Pamir Biological Institute that actually represents the highest botanical garden in the
Commonwealth of Independent States (CIS). Analysis were carried on fresh aggregate fruits, during the early maturation time and the period of full maturity (code 87 of the phenological growth stage according with the $\mathrm{BBCH}$ scale) and on dried fruits (Meier, 2003). All berries (50 fruits from each cultivar) were picked by hand in different parts of the plant, selected according to uniformity of shape and color, and delivered to laboratory for analysis.

The moisture contents of the fresh and dried mulberries were obtained by the AOAC method no. 934.06 (James, 1995). For the drying processing samples (initial moisture content close to $81.5 \%$ on wet basis) were distributed uniformly in a single layer in the sample tray, and then exposed immediately to the sun. Drying was continued until the sample reached the desired moisture level $(17 \%$ wet basis, reached until constant weight $<0.003 \mathrm{~g}$ in two successive measurements). The initial weight was recorded with an electronic balance (SE622, WVR, USA) with an accuracy of $0.01 \mathrm{~g}$.

To determine the total, reducing and non-reducing sugar contents a mulberry extract was obtained by using $5 \mathrm{~g}$ of fruit added to $100 \mathrm{~mL}$ of distilled hot $\left(40^{\circ} \mathrm{C}\right)$ water and three replicates were made for each chemical analysis. The samples were thoroughly homogenised for a few minutes with an Ultra Turrax (T25, IKA Werke, Staufen, Germany) and centrifuged at room temperature for $10 \mathrm{~min}$ at 3,000 rpm. After the mixture was filtered using two layers of Whatman ${ }^{\circledR} n^{\circ} 1$ filter paper, the solution was added with $10 \mathrm{~mL} \mathrm{HCl} \mathrm{(Sigma}$ Aldrich, St. Louis, MO, USA) and heated to boiling for $5 \mathrm{~min}$ using an electric furnace. The solution was neutralized to phenolphthalein with $10 \% \mathrm{NaOH}$ (Sigma Aldrich) and made up to $250 \mathrm{~mL}$. Finally the solution was used for titration against Fehling's solution (James, 1995). The values were expressed as percentage of sugar content as follows:

$$
\begin{gathered}
\% \text { Total sugars }=\frac{\text { factor }(4.95) \times \text { dilution }(250) \times 2.5}{\text { Titre } \times \text { m sample } \times 10} \\
\% \text { Reducing sugars }=\frac{\text { factor }(49.5) \times \text { dilution }(250) \times 2.5}{\text { Titre } \times \text { m sample } \times 10}
\end{gathered}
$$

where Titre is the volume of solution used for titration, and $m$ sample is the mass of mulberry used. The non-reducing sugar (sucrose) content was estimated as the difference between total sugar content and reducing sugar content (James, 1995).

The titratable acidity (TA) was determined by neutralization reaction as described in AOAC (AOAC, 1990).

The ascorbic acid content (vitamin $C$ ) was determined with the method of titration with 2,6-dichlorophenolindophenol (DCPIP) following the AOAC protocol and it was calculated using the formula: 
Ascorbic acid content $\left(\mathrm{mg} 100 \mathrm{~g}^{-1} \mathrm{DM}\right)=$

$$
\frac{\text { Titre } \times V E \times V_{1} \times 100 \times 100}{V_{2} \times S \times 1,000 \times Y}
$$

where Titre is the volume of solution used for titration, $V E=$ ascorbic acid equivalent of $1 \mathrm{~mL}$ DCPIP ( $\left.\mathrm{mg} \mathrm{mL}^{-1}\right), V_{1}=$ total extract volume $(\mathrm{mL}), V_{2}=$ titrated extract volume $(\mathrm{mL}), S=$ sample weight, $Y=$ sample dry matter (\%). Three replicates were taken for each chemical analysis.

\section{Sensory evaluation}

In order to have additional parameters for evaluating fruit quality, a 1 to 5 point hedonic scale was defined according to the following general guiding principles: $5=$ optimum, 4 = good, 3 = fair, 2 = limit to marketability, 1 = very bad, not edible. All interviewees (15 persons) were questioned taking into account flavour/taste, appearance and texture. Each panel evaluated three samples of each cultivar at the full ripening stage and after the drying processing. The mean scores were reported.

\section{Statistical analysis}

The degree of diverseness that exists in terms of qualitative and quantitative characters related to morphology and growth of the wild mulberry plants distributed in the different sites of the West Pamirs Valley has been calculated as percentage. All statistical analyses were performed using SPSS Statistics 22 statistical package software (SPSS Statistics 22, 2015, IBM, Italy) for Windows. The obtained data were treated using a one way analysis of variance (ANOVA), and the means were separated using Tukey's test $(P \leq 0.05)$. All acquired data are reported as an average of three years and no statistical differences were observed among the years of the observation.

\section{Results and discussion}

Field investigations revealed that in the Western Pamirs two species of mulberry grow, black mulberry (Morus nig$r a$ L.) and white mulberry (Morus alba L.). The first is represented by one cultivar ('Shatut') and revealed to live from 1,000 to $2,100 \mathrm{~m}$ a.s.l.; the second type showed a great polymorphism counting 50 cultivars and it is widely distributed throughout the region from 1,000 to 2,400 $\mathrm{m}$ a.s.l. The effects of climate change in an area with strong agricultural suitability as the Pamir today is highly regarded. Unfortunately, the Pamir region is not sufficiently monitored for the assessment of climate change which should be recorded in terms of temperature and rainfall (total and distribution). The effects on vegetation are even less noticeable and, even today, they do not seem to be able to influence the behavior of long-lived species such as mulberry, although some relevant changes have been reported in terms of glacier restriction (UngerShayesteh et al., 2013). At the local level, in the areas of greatest interest for the species, no significant changes in terms of phenology of blooming, of vegetative development and of ripening have been evidenced, showing that a significant effect of climate change on the main fruit crop of this area of Tajikistan is not determinable today (Unger-Shayesteh et al., 2013). Based on age results (Table 1), the most favourable conditions in terms of tree growth exist in Vanch, Rushan, and Shugnan area where the oldest mulberry trees where found. In fact more than $50 \%$ of plants for each sites showed an age between 51 and 100 years and, in the lower part of Vanch (in the villages of Buna, Changkang Zugo and Yazgulyamskoy) some trees (7.6\%) aged between 100 and 200 years old. In the Ishkashim, Roshtkala and Khrog valley, on the contrary, the highest percentage of trees (respectively 56.3, 96.2 and $96 \%$ ) aged between 16 and 50 years while outside of all the monitored sites in the West Pamir Valley less than 5\% of the total trees evaluated have achieved 15 years-old. The trunk circumference is an important biological aspect related to the industrial significance and it is directly dependent on the tree age and the environment conditions. In $64.5 \%$ of the trees the size of the trunk circumference is from 0.1 to $1.0 \mathrm{~m}$ but the maximum values (2.6-3.0 $\mathrm{m}$ ) were measured in trees found in the Vanch and Rushan districts (respectively 2.0 and $1.8 \%$ ) where the oldest trees were found. The distribution percentage of four types of crown shape observed is similar for all the growing areas indicating that this feature is not closely related to the ecological characteristics of the territory but rather it is a morphological characteristic linked to single plants. It is not always possible to assign a defined shape to the plants while the pyramidal and round crown shape seemed to have a similar distribution. The polymorphism of mulberry leaves has long attracted the attention of researchers due to the interest of the different species for the sericulture industry (Qin et al., 2012).

Among all the morphological characteristics detected (Table 3), the leaf blade evidenced the highest differentiation in the investigated areas; the Vanch and the Rushan area collect respectively 44.3 and $40.5 \%$ of the whole leaf blades while the symmetrically lobed leaf blades assumed half of the distribution in the other valleys. According to the literature (Zhukovsky, 1971), the number of blades in mulberry leaves varies from 3 to 11 . Five-lobed forms are the most rep-

TABLE 2. Distribution percent of mulberry growth, trunk and crown shape traits along the six selected sites in Gorno

\begin{tabular}{|c|c|c|c|c|c|c|c|c|c|c|c|c|}
\hline \multirow{2}{*}{$\begin{array}{l}\text { Sites in the } \\
\text { West } \\
\text { Pamirs' Valley }\end{array}$} & \multicolumn{4}{|c|}{$\%$ Tree age $(\mathrm{y})$} & \multicolumn{4}{|c|}{$\%$ Trunk circumference $(\mathrm{m})$} & \multicolumn{4}{|c|}{$\%$ Crown shape } \\
\hline & $<15$ & $16-50$ & $51-100$ & $>100$ & $0.1-1.0$ & $1.1-1.5$ & $1.6-2.5$ & $2.6-3.0$ & $\begin{array}{c}\text { Widely } \\
\text { pyramidal }\end{array}$ & Pyramidal & Incorrectly & Round \\
\hline Vanch & 9.0 & 32.4 & 51.0 & 7.6 & 47.8 & 44.4 & 5.8 & 2.0 & 7.6 & 10.7 & 67.1 & 14.6 \\
\hline Rushan & 4.0 & 25.4 & 63.7 & 6.9 & 66.7 & 26.5 & 5.0 & 1.8 & 3.2 & 12.3 & 69.3 & 15.2 \\
\hline Shugnan & 4.5 & 31.3 & 60.8 & 3.4 & 59.6 & 39.4 & 1.0 & 0.0 & 2.6 & 15.1 & 64.3 & 18.0 \\
\hline Ishkashim & 6.0 & 56.3 & 31.7 & 6.0 & 73.4 & 26.6 & 0.0 & 0.0 & 1.0 & 12.0 & 70.8 & 16.2 \\
\hline Roshtkala & 1.8 & 96.2 & 2.0 & 0.0 & 72.0 & 27.0 & 1.0 & 0.0 & 2.2 & 12.0 & 71.1 & 14.7 \\
\hline Khorog & 1.5 & 96.0 & 2.0 & 0.5 & 67.3 & 26.5 & 5.2 & 1.0 & 3.0 & 12.5 & 69.6 & 14.9 \\
\hline Average & 4.5 & 56.3 & 35.2 & 4.1 & 64.5 & 31.7 & 3.0 & 0.8 & 3.3 & 12.4 & 68.7 & 15.6 \\
\hline
\end{tabular}
Badakhshan Autonomous Oblast (GBAO) Province of the West Pamirs' Valley. 
TABLE 3. Distribution percent of mulberry leaf morphological characteristics along the six selected sites in Gorno Badakhshan Autonomous Oblast (GBAO) Province of the West Pamirs' Valley.

\begin{tabular}{|c|c|c|c|c|c|c|c|c|c|c|c|c|c|c|c|}
\hline \multirow[b]{2}{*}{$\begin{array}{l}\text { Sites in } \\
\text { the West } \\
\text { Pamirs' } \\
\text { Valley }\end{array}$} & \multicolumn{3}{|c|}{$\%$ Leaf blade } & \multicolumn{3}{|c|}{$\%$ Blade } & \multicolumn{3}{|c|}{$\%$ Leaf apex } & \multicolumn{3}{|c|}{$\%$ Leaf base } & \multicolumn{3}{|c|}{$\%$ Leaf margin } \\
\hline & $\begin{array}{l}\frac{0}{0} \\
\frac{1}{3}\end{array}$ & 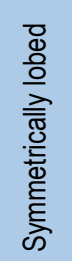 & 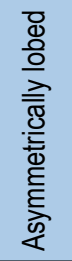 & $n^{\circ} 3$ & $n^{\circ} 5$ & $n^{\circ} 7$ & 壳 & 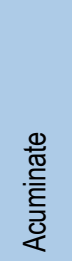 & 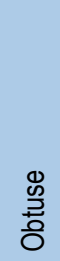 & 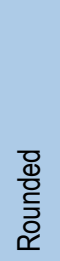 & 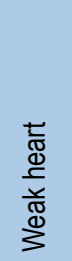 & 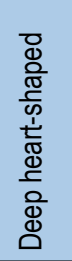 & 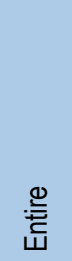 & 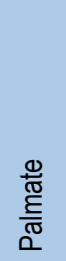 & 蒙 \\
\hline Vanch & 44.3 & 37.2 & 18.5 & 35.7 & 57.6 & 6.7 & 49.8 & 42.8 & 7.4 & 4.5 & 30.5 & 65.0 & 23.9 & 38.0 & 38.1 \\
\hline Rushan & 40.5 & 39.0 & 20.5 & 43.6 & 53.2 & 3.2 & 50.2 & 42.5 & 7.3 & 3.9 & 34.0 & 62.1 & 28.1 & 39.6 & 32.3 \\
\hline Shugnan & 23.1 & 49.1 & 27.8 & 37.3 & 59.7 & 3.0 & 53.7 & 40.4 & 5.9 & 3.4 & 23.4 & 73.2 & 10.7 & 49.3 & 40.0 \\
\hline Ishkashim & 10.1 & 52.3 & 37.6 & 38.4 & 60.0 & 1.6 & 59.1 & 35.6 & 5.3 & 5.4 & 24.6 & 70.0 & 17.9 & 53.0 & 29.1 \\
\hline Roshtkala & 10.0 & 55.0 & 35.0 & 37.2 & 60.5 & 2.3 & 60.3 & 35.1 & 4.6 & 2.6 & 28.3 & 69.1 & 20.6 & 55.1 & 24.3 \\
\hline Khorog & 15.3 & 50.2 & 34.5 & 41.6 & 54.7 & 3.7 & 57.2 & 37.9 & 4.9 & 3.9 & 27.9 & 68.2 & 27.6 & 50.3 & 22.1 \\
\hline
\end{tabular}

TABLE 4. Distribution percent of mulberry tree leaf and stem size characteristics along the six selected sites in Gorno Badakhshan Autonomous Oblast (GBAO) Province of the West Pamirs' Valley.

\begin{tabular}{|c|c|c|c|c|c|c|c|c|c|c|c|c|c|c|c|}
\hline \multirow{3}{*}{$\begin{array}{l}\text { Sites of the } \\
\text { West Pamirs' } \\
\text { Valley }\end{array}$} & \multicolumn{12}{|c|}{$\%$ Leaf size $(\mathrm{mm})$} & \multicolumn{3}{|c|}{ \% Stem size $(\mathrm{mm})$} \\
\hline & \multicolumn{2}{|c|}{$70-80$} & \multicolumn{2}{|c|}{$81-90$} & \multicolumn{2}{|c|}{$91-100$} & \multicolumn{2}{|c|}{$101-110$} & \multicolumn{2}{|c|}{$111-120$} & \multicolumn{2}{|c|}{$121-130$} & \multirow{2}{*}{$30-40$} & \multirow{2}{*}{$40-50$} & \multirow{2}{*}{$50-60$} \\
\hline & Length & Width & Length & Width & Length & Width & Length & Width & Length & Width & Length & Width & & & \\
\hline Vanch & 0.0 & 10.3 & 2.5 & 25.0 & 5.8 & 23.2 & 25.3 & 19.1 & 35.0 & 5.7 & 31.4 & 16.7 & 35.0 & 41.0 & 24.0 \\
\hline Rushan & 0.0 & 15.1 & 5.0 & 28.0 & 7.2 & 25.3 & 30.1 & 26.0 & 35.6 & 3.2 & 22.1 & 2.4 & 37.3 & 43.2 & 19.5 \\
\hline Shugnan & 0.0 & 20.0 & 8.3 & 30.5 & 10.5 & 30.5 & 35.2 & 10.3 & 27.0 & 5.5 & 19.0 & 3.2 & 38.0 & 42.5 & 19.5 \\
\hline Ishkashim & 0.0 & 27.1 & 12.6 & 32.6 & 18.2 & 33.4 & 44.1 & 6.9 & 25.1 & 0.0 & 0.0 & 0.0 & 45.0 & 44.4 & 10.6 \\
\hline Roshtkala & 0.0 & 25.0 & 12.0 & 30.2 & 18.1 & 32.1 & 45.0 & 12.7 & 20.3 & 0.0 & 4.6 & 0.0 & 45.1 & 44.0 & 10.9 \\
\hline Khorog & 0.0 & 15.0 & 6.0 & 27.5 & 7.8 & 24.1 & 35.0 & 29.1 & 30.6 & 3.0 & 20.6 & 1.3 & 37.0 & 43.1 & 19.9 \\
\hline
\end{tabular}

TABLE 5. Morphological traits of mulberry fruit along the six selected sites in Gorno Badakhshan Autonomous Oblast (GBAO) Province of the West Pamirs' Valley. Data are means \pm SD $(n=50)$.

\begin{tabular}{|c|c|c|c|c|c|}
\hline \multirow{2}{*}{$\begin{array}{l}\text { Sites of the West } \\
\text { Pamirs' Valley }\end{array}$} & \multicolumn{3}{|c|}{ Size of aggregate fruit } & \multicolumn{2}{|c|}{ Size of aggregate stalk } \\
\hline & Length $(\mathrm{mm})$ & Width $(\mathrm{mm})$ & Weight (g) & Length (mm) & Thickness (mm) \\
\hline Vanch & $21.9 \pm 1.7 a^{*}$ & $12.9 \pm 1.3 \mathrm{a}$ & $1.8 \pm 0.1 \mathrm{a}$ & $7.9 \pm 0.6 b$ & $1.0 \pm 0.1 \mathrm{~ns}^{* *}$ \\
\hline Rushan & $21.1 \pm 1.7 \mathrm{a}$ & $12.1 \pm 1.6 \mathrm{a}$ & $1.7 \pm 0.1 \mathrm{a}$ & $8.0 \pm 0.5 b$ & $1.0 \pm 0.1 \mathrm{~ns}$ \\
\hline Shugnan & $18.0 \pm 1.7 b$ & $12.0 \pm 1.5 \mathrm{a}$ & $1.6 \pm 0.2 a b$ & $6.1 \pm 0.2 c$ & $1.0 \pm 0.1 \mathrm{~ns}$ \\
\hline Ishkashim & $13.9 \pm 1.4 c$ & $0.8 \pm 0.6 b$ & $0.9 \pm 0.01 c$ & $6.1 \pm 0.2 c$ & $1.0 \pm 0.1 \mathrm{~ns}$ \\
\hline Roshtkala & $15.9 \pm 1.4 b c$ & $11.1 \pm 1.0 \mathrm{a}$ & $1.0 \pm 0.08 c$ & $14.7 \pm 1.4 \mathrm{a}$ & $1.0 \pm 0.1 \mathrm{~ns}$ \\
\hline Khorog & $18.0 \pm 1.7 b$ & $12.0 \pm 1.4 \mathrm{a}$ & $1.5 \pm 0.2 b$ & $14.9 \pm 1.6 \mathrm{a}$ & $1.0 \pm 0.1 \mathrm{~ns}$ \\
\hline
\end{tabular}

${ }^{*}$ Means within columns followed by different letters are significant at $\mathrm{P} \leq 0.05$ according to Tukey's test.

${ }^{* *}$ ns $=$ not significant.

TABLE 6. Distribution percent of mulberry fruit color and shape characteristics along the six selected sites in Gorno Badakhshan Autonomous Oblast (GBAO) Province of the West Pamirs' Valley.

\begin{tabular}{|c|c|c|c|c|c|c|c|c|c|c|c|}
\hline \multirow{2}{*}{$\begin{array}{l}\text { Sites of the } \\
\text { West Pamirs' } \\
\text { Valley }\end{array}$} & \multicolumn{5}{|c|}{$\%$ Color } & \multicolumn{6}{|c|}{$\%$ Shape } \\
\hline & White & $\begin{array}{l}\text { Light } \\
\text { yellow }\end{array}$ & $\begin{array}{l}\text { Purple } \\
\text { pink }\end{array}$ & $\begin{array}{l}\text { Light } \\
\text { pink }\end{array}$ & $\begin{array}{l}\text { Dark } \\
\text { red }\end{array}$ & Cylindrical & Oblate & Elongate & $\begin{array}{c}\text { Oval- } \\
\text { cylindrical }\end{array}$ & $\begin{array}{l}\text { Cylindro- } \\
\text { conical }\end{array}$ & $\begin{array}{l}\text { Square- } \\
\text { cylindrical }\end{array}$ \\
\hline Vanch & 64.7 & 10.9 & 4.9 & 8.5 & 11.0 & 12.3 & 6.0 & 25.0 & 37.8 & 12.6 & 6.3 \\
\hline Rushan & 55.5 & 20.3 & 3.0 & 10.0 & 11.2 & 8.5 & 5.7 & 34.8 & 40.5 & 6.4 & 4.1 \\
\hline Shugnan & 40.3 & 30.1 & 15.5 & 6.7 & 7.4 & 4.2 & 4.2 & 35.7 & 50.9 & 5.0 & - \\
\hline Ishkashim & - & 50.0 & - & 25.0 & 25.0 & - & - & 50.0 & 50.0 & - & - \\
\hline Roshtkala & - & 50.0 & - & 25.0 & 25.0 & - & - & 50.0 & 50.0 & - & - \\
\hline Khorog & 30.0 & 30.6 & 2.5 & 16.4 & 20.5 & & & 49.4 & 42.0 & 5.6 & 3.0 \\
\hline
\end{tabular}


resented, ranging from a minimum of $53.2 \%$ to a maximum of $60.5 \%$ of the total number of studied forms in each area while the seven-lobed form does not exceed $6.7 \%$. The maximum length of mulberry leaves (Table 4) was in the range of 121-130 mm and it was found in the Vanch valley with the highest percentage $(35.0 \%)$ while the minimum was in the range of 81-90 $\mathrm{mm}$ in the Ishkashim and Roshtkala valley (respectively $27.1 \%$ and $25.0 \%$ ). Generally, the largest leaves were observed in youngest trees, in cultivated area (orchard and garden) and at lower altitude. As seen from Table 5 , the size of aggregate mulberry fruits in the Western Pamirs ranged from 13.9 to $21.9 \mathrm{~mm}$ length and from 0.8 to $12.9 \mathrm{~mm}$ large. The morphological traits of higher performance aggregate fruits have been observed in the Vanch and Rushan valley which showed statistically significant differences from the other districts. Mulberry fruits change the color from green to black purple through red along maturity phases (Qin et al., 2010); in the Western Pamirs five classes of colors were observed for the mulberry fruits (Table 6). All of them were evidenced in Vanch and Rushan areas and the white color fruits were the most abundant $(64.7 \%$ and $55.5 \%$ respectively).

\section{Qualitative analysis of mulberry}

The analyses on the qualitative fruit traits of the selected mulberry cultivars showed important differences in terms of general sugars, reducing sugars and sucrose (Figure 1), ascorbic acid and titratable acidity content (Table 7). As reported in Figure 1, all cultivars showed an increasing trend in the content of the total and reducing sugars as maturity progressed from unripe to full ripened stage while the sucrose content maintained the same values. The total content of sugars among mulberry fruits widely varied among the different cultivars analysed; at full-ripened stage the highest amount was recorded for the cv. Bedonia (24.0 $100 \mathrm{~g}^{-1}$ FW) while the lowest amount was determined in the black mulberry cv. Shatut (12.8 g $\left.100 \mathrm{~g}^{-1} \mathrm{FW}\right)$ whose values are in the same range of those reported in previous study in Turkey (Elmaci and Altug, 2002). As far as the drying process generally increased the total sugars, the reducing sugars and the sucrose and this behaviour is likely due to the water loss which greatly affects the concentration of total sugars during the time of the exposure of the fruits to the sun. The cv. Muzzafar after the drying process has showed the highest

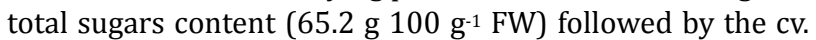
Marvori that has maintained a high profile both in the fresh fruits $\left(21.1{\left.\mathrm{~g} 100 \mathrm{~g}^{-1} \mathrm{FW}\right)}\right.$ and in the processed ones $(61.1 \mathrm{~g}$ $100 \mathrm{~g}^{-1} \mathrm{FW}$ ). The high values in the fresh mulberry fruits of cv. Bedonia were not maintained after the drying process, probably due to the low water losses that occurred under the sun effect and the small initial weight of the fresh fruits. Changes in ascorbic acid content were strongly related to the ripeness stage and the drying process (Table 7). Among the pre-harvest factors the time of harvest is one of the most important that could affect the qualitative composition of fruits (Lee and Kader, 2000). The ascorbic acid content increased in fruits as they ripen. At the early ripening stage the variability of the ascorbic acid content between the species and the cultivar was lower than at the full ripening. No statistically differences were observed among the black mulberry (cv. Shatut) and the white mulberry (cv. Muzzafar) which showed the highest ascorbic acid values (respectively 28.5 and $28.3 \mathrm{mg} 100 \mathrm{~g}^{-1} \mathrm{DM}$ ). These values were in accordance with the findings of Lale and Ozcagiran (1996) that reported that ascorbic acid content in black mulberry was $26.6 \mathrm{mg}$ $100 \mathrm{~g}^{-1} \mathrm{DM}$. As the ripening goes on, all mulberry cultivars

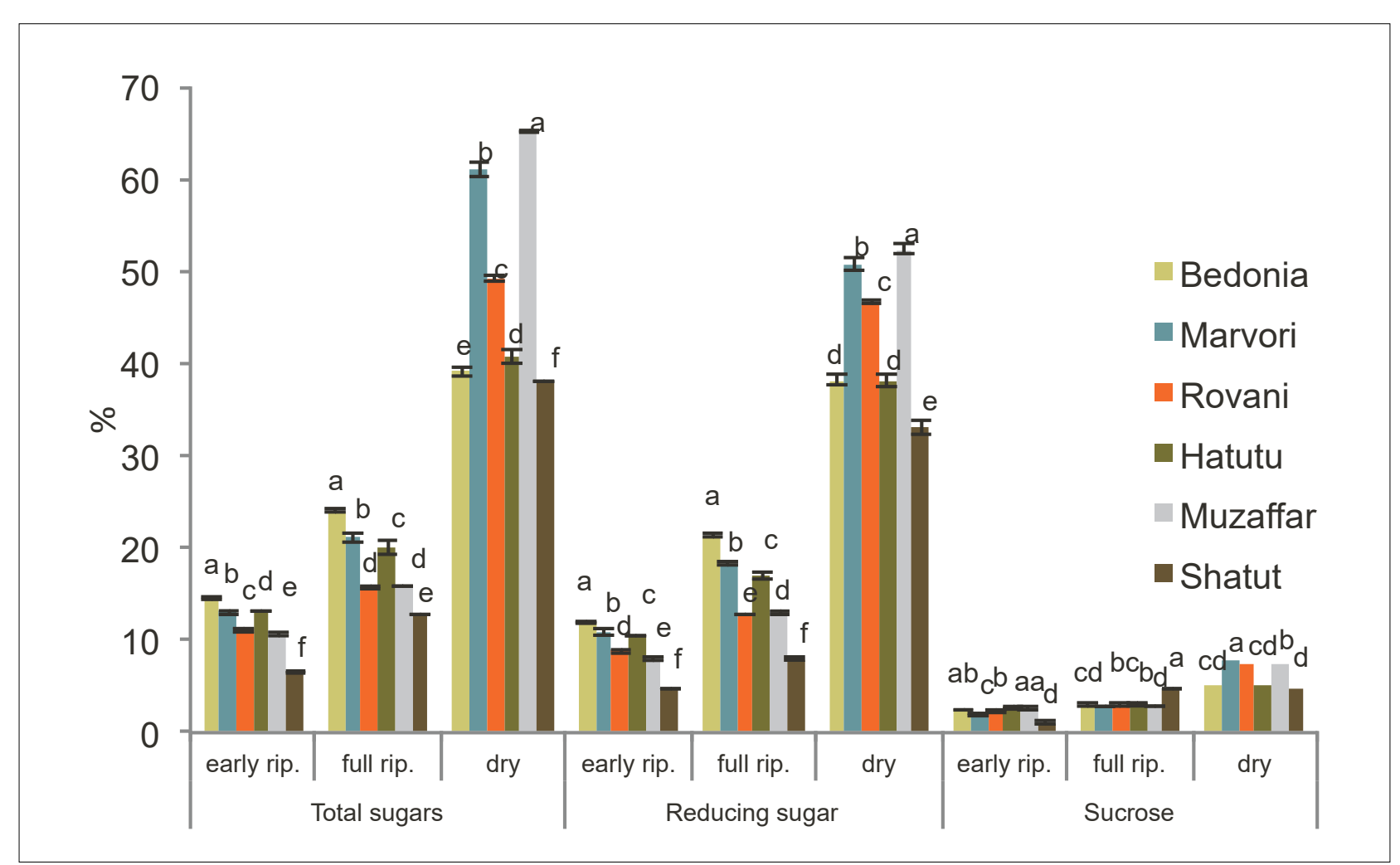

FIGURE 1. Total sugars, reducing sugars and sucrose contents (\%) of fresh mulberry (at early and full ripening stages) and dry mulberry fruits in the Pamir Biological Institute. The means within the early, full ripening and dry stages followed by different letters (a-f) are significantly different at $P \leq 0.05$ according to Tukey's test. The bar of error corresponds to the standard deviation between repetitions $(n=3)$. 
TABLE 7. Fruit quality biochemical traits of fresh mulberry at early and full ripening stages, and dry fruit. Data are mean values $\pm \operatorname{SD}(n=3)$.

\begin{tabular}{|c|c|c|c|c|c|c|c|c|c|c|c|c|}
\hline \multirow{3}{*}{$\begin{array}{l}\begin{array}{l}\text { Cultivars of } \\
\text { mulberry }\end{array} \\
\text { Bedonia }\end{array}$} & \multicolumn{4}{|c|}{ Early ripening } & \multicolumn{4}{|c|}{ Full ripening } & \multicolumn{4}{|c|}{ Dry } \\
\hline & \multicolumn{2}{|c|}{$\begin{array}{c}\text { Ascorbic acid } \\
\left.\text { (mg } 100 \mathrm{~g}^{-1} \mathrm{DM}\right)\end{array}$} & \multicolumn{2}{|c|}{$\begin{array}{c}\text { Titratable acidity } \\
(\%)\end{array}$} & \multicolumn{2}{|c|}{$\begin{array}{c}\text { Ascorbic acid } \\
\left.\text { (mg } 100 \mathrm{~g}^{-1} \mathrm{DM}\right)\end{array}$} & \multicolumn{2}{|c|}{$\begin{array}{c}\text { Titratable acidity } \\
(\%)\end{array}$} & \multicolumn{2}{|c|}{$\begin{array}{c}\text { Ascorbic acid } \\
\left.\text { (mg } 100 \mathrm{~g}^{-1} \mathrm{DM}\right)\end{array}$} & \multicolumn{2}{|c|}{$\begin{array}{c}\text { Titratable acidity } \\
(\%)\end{array}$} \\
\hline & $25.0 \pm 0.47$ & $b^{*}$ & $0.8 \pm 0.04$ & $d$ & $28.0 \pm 0.8$ & $f$ & $0.5 \pm 0.0$ & $\mathrm{~b}$ & $12.8 \pm 0.1$ & $b$ & $1.1 \pm 0.1$ & $b c$ \\
\hline Marvori & $23.2 \pm 0.17$ & c & $1.0 \pm 0.16$ & c & $35.8 \pm 0.1$ & $b$ & $0.3 \pm 0.1$ & $d$ & $10.3 \pm 0.0$ & $d$ & $1.0 \pm 0.1$ & $b c$ \\
\hline Rovani & $25.3 \pm 0.14$ & b & $2.0 \pm 0.15$ & $b$ & $32.0 \pm 1.0$ & $d$ & $0.5 \pm 0.0$ & $b c$ & $8.4 \pm 0.1$ & e & $0.9 \pm 0.1$ & $d$ \\
\hline Hatutu & $23.0 \pm 0.16$ & c & $1.8 \pm 0.08$ & $b$ & $29.0 \pm 0.1$ & e & $0.4 \pm 0.0$ & c & $10.7 \pm 0.1$ & c & $1.8 \pm 0.1$ & a \\
\hline Muzaffar & $28.3 \pm 0.20$ & a & $2.2 \pm 0.22$ & a & $35.0 \pm 0.6$ & c & $0.4 \pm 0.0$ & $b c$ & $10.8 \pm 0.1$ & c & $1.1 \pm 0.1$ & $\mathrm{~cd}$ \\
\hline Shatut & $28.5 \pm 0.08$ & a & $2.0 \pm 0.05$ & $b$ & $38.0 \pm 0.1$ & a & $1.0 \pm 0.1$ & $a$ & $13.9 \pm 0.1$ & a & $1.2 \pm 0.1$ & $b$ \\
\hline
\end{tabular}

* Means within columns followed by different letters are significantly at $P \leq 0.05$ according to Tukey's test.

showed the increase of the total content in ascorbic acid, at the full ripening more than $50 \%$ increase was observed for the cv. Marvori, while the black 'Shatut' accounted $38.0 \mathrm{mg}$ $100 \mathrm{~g}^{-1} \mathrm{DM}$ and confirmed the highest ascorbic acid content. All the cultivars showed the ascorbic acid content losses as consequence of the drying process probably due to the enzymatic reactions and oxidations caused by the exposure to the sunlight and the heat. Dehydration of mulberry fruits resulted in a decrease of the ascorbic acid content ranging between a minimum of $54.2 \%$ and a maximum of $73.7 \%$. The greatest ascorbic acid loss was observed for the cv. Rovani ( $8.4 \mathrm{mg} 100 \mathrm{~mL}^{-1}$ ) while the black mulberry still confirmed the highest ascorbic acid content $13.9 \mathrm{mg} 100 \mathrm{~mL}^{-1}$. The titratable acidity (TA) (Table 7) varied significantly among cultivars both in the fresh fruits at the early and at the full ripening stage and after the drying processing. Generally higher values of TA in a typical fruit are negatively linked with the flavour and consumer acceptance (Chitarra and Chitarra, 2005 ) if they are not equilibrated by high sugars values. As well as measured for all the sugars, a reduction in TA was observed with the progress of the ripening and it was probably caused by the mulberry fruits respiration process during the time. The highest value at the early stage $(2.2 \%)$ was noted in 'Muzzafar' while the lowest was in the cv. Bedonia; these data were confirmed by the less acidic content also in the full ripening stage $(0.3 \%)$. The black mulberry 'Shatut' with $1.0 \%$ acidity was statistically different from the other genotypes only at the full ripening showing the highest TA values and confirming data reported by Ercisli and Orhan (2007). The sweetness and acidity components affect the flavor and the taste of mulberry fruits; in fresh fruits this ratio (data not reported) was significantly different among the cultivars for each ripening time and increased whit the full ripening. In dried fruits the highest value was found in 'Marvori' while a similar ratio was observed for the white mulberry 'Bedonia' and the black mulberry 'Shatut', confirming the sensory profile and preference of the panelist's data reported in the sensory evaluation (Figure 2).

\section{Conclusion}

As in many parts of Central Asia, Northern India, Afghanistan, Iran, Caucasus, and Turkey, and also in the Pamir area, the fruits of mulberry show important characteristics to consider them of interest for the human nutrition purpose; in fact the ornamental role, mainly recognized especially in ancient time in some countries as Italy, is secondary if compared to their potential use for food. The main difference from other countries lays in the investigated sites that belong to a natural and preserved area well representative for high biodiversity, and the genotypes are not from an improved selection of collected fields of germplasm.

The Vanch and the Rushan valley, probably due to the less extreme climatic conditions and the best properties of the soil, evidenced in all the sites the highest rate of variability and the most promising genotypes in terms of morphological characteristics of the mulberry fruits. In view of the results, obtained from the qualitative analysis of the fruits, the consumption of the fresh fruits at the full ripening stage should be strongly recommended due to the a high ascorbic acid content. Among white mulberry cultivars, the fruit of cv. Marvori have maintained the highest nutritional quality while those of $\mathrm{cv}$. Bedonia excelled in reducing and total sugars during all the ripening time, suggesting a relation for a better taste. Although the sun-drying process affects the
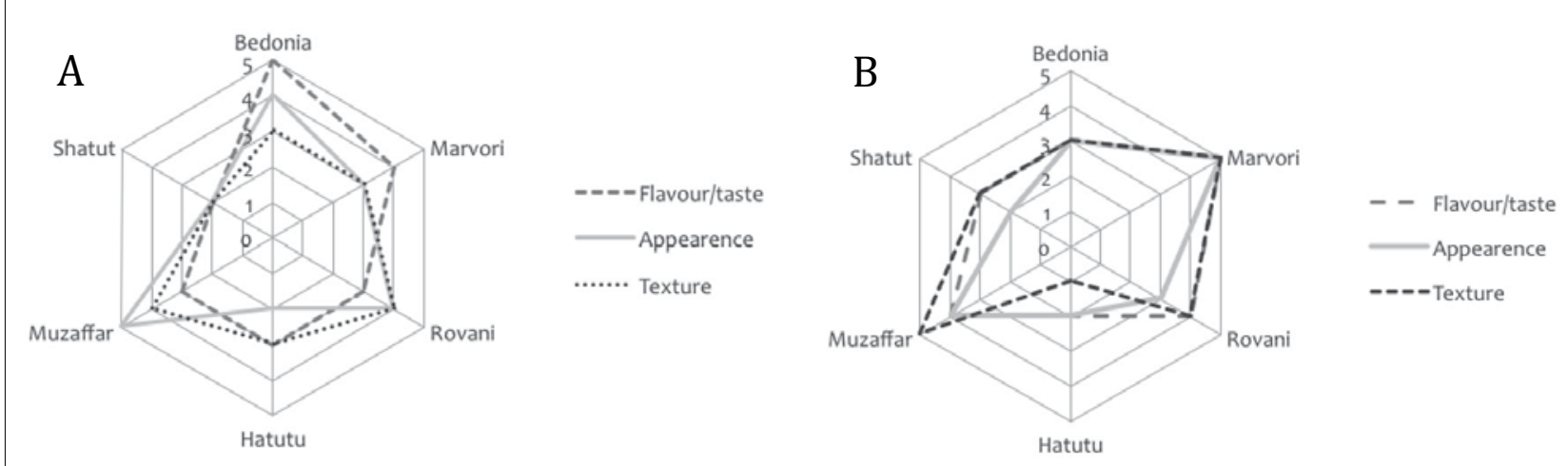

FIGURE 2. Fresh full ripening (A) and dried (B) mulberry fruit sensory evaluation $(n=15)$. 
ascorbic acid content, lowering it in all cultivars, this technique is the only one actually adaptable to preserve fruits in these territories due to the favourable environmental conditions. The knowledge and the choice of the black mulberry cv. Shatut could valorise this process and all the processed products, improving the commercial value of the dried fruit and their derivatives.

\section{References}

Aknazarov, O., Dadabaev, I., and Melnichkov, D. (2002). Ecotourism in the Pamir region: problems and perspectives. Mountain Res. Dev. 22, 188-190. https://doi.org/10.1659/0276-4741(2002)022[0188: EITPRP]2.0.CO;2.

AOAC (1990). Official Methods of Analysis. Analytical Chemist, $15^{\text {th }}$ ed. (USA, Washington DC).

Atmakuri, A.R., Chaudhury, R., Malik, S.K., Kumar, S., Ramachandran, R., and Qadri, S.M.H. (2009). Mulberry biodiversity conservation through cryopreservation. In Vitro Cell. Dev. Biol. Plant 45, 639-649. https://doi.org/10.1007/s11627-008-9185-3.

Chitarra, M.I.F., and Chitarra, A.B. (2005). Post-Harvest Fruits and Vegetables: Physiology and Handling, $2^{\text {nd }}$ ed. (Lavras, Brazil: UFLA), $785 \mathrm{pp}$.

El Obeidi, A.A. (2005). Flowering and fruiting of cv. Pakistan mulberry under saline soil conditions in Egypt. Fruits 60, 405-411. https:// doi.org/10.1051/fruits:2005046.

Elmaci, Y., and Altug, T. (2002). Flavour evaluation of three black mulberry (Morus nigra) cultivars using GC/MS, chemical and sensory data. J. Sci. Food Agric. 82, 632-635. https://doi.org/10.1002/ jsfa.1085.

Ercisli, S., and Orhan, E. (2007). Chemical composition of white (Morus alba), red (Morus rubra) and black (Morus nigra) mulberry fruits. Food Chem. 103, 1380-1384. https://doi.org/10.1016/j.foodchem.2006.10.054

FAO (Food and Agriculture Organization of the United Nations) (2010). Republic of Tajikistan: Unlocking Pamirs' development potential. Participatory investment planning workshop report (Rome: FAO).

Frison, E.A., Smith, I.F., Johns, T., Cherfas, J., and Eyzaguirre, P. (2006). Agricultural biodiversity, nutrition and health: Making a difference to hunger and nutrition in the developing world. Food Nut. Bul. 27, 167-179. https://doi.org/10.1177/156482650602700208.

Giuliani, A., Van Oudenhoven, F., and Mubalieva, S. (2011). Agricultural biodiversity in the Tajik Pamirs. Mountain Res. Dev. 31, 16-26. https://doi.org/10.1659/MRD-JOURNAL-D-10-00109.1.

GOT (Government of Tajikistan) (2002). Economic development programme for Tajikistan until 2015 (Dushanbe, Tajikistan).

Gray, E. (1990). Evidence of phenotypic plasticity in mulberry (Morus L.). Castanea 55, 272-281.

Hannam, I.D. (2013). Transboundary resource management strategies in the Pamir Mountain region of Tajikistan. In Land and Post-Conflict Peace Building, J. Unruh and R.C. Williams, eds. (London: Earthscan Pub.).

James, C.S. (1995). Analytical chemistry of food (Plymouth, UK: Seale Hayne Faculty of Agriculture, Food and Land Use, Department of Agriculture and Food Studies, University of Plymouth) 1, 96-97.

Lale, H., and Ozcagiran, R. (1996). A study on pomological, phonologic and fruit quality characteristics of mulberry (Morus sp.) species. Derim 131,77-182.
Lee, S.K., and Kader, A.A. (2000). Preharvest and postharvest factors influencing vitamin $\mathrm{C}$ content of horticultural crops. Postharvest Biol. and Technol. 20, 207-220. https://doi.org/10.1016/S09255214(00)00133-2.

Meier, U. (2003). Phenology: An Integrative Environmental Science. Phenological Growth Stages (The Netherlands: Kluwer Academic Publishers), p. 269-283. https://doi.org/10.1007/978-94-0070632-3_17.

Middleton, R. (2016). History of the development of the Pamir region of Tajikistan (Gorno-Badakhshan). In Mapping Transition in the Pamirs: With Case Studies on the Changing Human Environmental Landscapes, H. Kreutzmann, and T. Watanabe, eds. (Springer).

Moustafa, A.R.A., Abdelwahab, R.H., Zaghloul, M.S., Salman, A.A., and Ahmed, A.A. (2014). Age structure of Ficus benghalensis L.: a threatened introduced population in Ismailia, Egypt. Life Sci. J. 11, 90-97.

Ozgen, M., Serc, S., and Kaya, C. (2009). Phytochemical and antioxidant properties of anthocyanin-rich Morus nigra and Morus rubra fruits. Sci. Hortic. 119, 275-279. https://doi.org/10.1016/j.scienta.2008.08.007

Qin, C., Li, Y., Niu, W., Ding, Y., Zhang, R., and Shang, X. (2010). Analysis and characterisation of anthocyanins in mulberry fruit. Czech J. Food Sci. 28, 117-126.

Qin, J., He, N., Wang, Y., and Xiang, Z. (2012). Ecological issues of mulberry and sustainable development. J. Res. Ecol. 3, 330-339.

Rautiainen, M., Mõttus, M., Stenberg, P., and Ervasti, S. (2008). Crown envelope shape measurements and models. Silva Fennica 42, 19-33. https://doi.org/10.14214/sf.261.

Unger-Shayesteh, K., Vorogushyn, S., Farinotti, D., Gafurov, A., Duethmann, D., Mandychev, A. and Merz, B. (2013). What do we know about past changes in the water cycle of Central Asian headwaters? A review. Glob. and Plan. Change 110, 4-25. https://doi. org/10.1016/j.gloplacha.2013.02.004.

Winn, A.A. (1996). Adaptation to fine-grained environmental variation: an analysis of within-individual leaf variation in an annual plant. Evolution 76, 1569-1580. https://doi.org/10.2307/2410651.

Zhukovsky, P.M. (1971). Cultivated Plants and Their Relatives (Leningrad, URSS: Kolos), 751 pp.

Received: May 31, 2016

Accepted: Feb. 9, 2017 